\title{
O RACJONALNOŚCI DYDAKTYKI JAKO PRZEDMIOTU NAUCZANIA I JAKO SUBDYSCYPLINY PEDAGOGICZNEJ
}

\begin{abstract}
Mieszalski Stefan, O racjonalności dydaktyki jako przedmiotu nauczania i jako subdyscypliny pedagogicznej [On Rationality of Didactics as an Academic Subject and as a Pedagogical Branch]. Studia Edukacyjne nr 47, 2018, Poznań 2018, pp. 81-93. Adam Mickiewicz University Press. ISSN 1233-6688. DOI: $10.14746 /$ se.2018.47.6

Within pedagogical sciences, didactics appears in at least two forms: as a subject taught in higher education and as one of branches of pedagogy. That is why in the field of didactics there is more than one type of rationality; they vary with respect to different purposes of two forms of didactics mentioned above.

The main purpose of the article is to analyze some issues related to rationality present in both forms of didactics. In the context of the subject taught in universities, several issues are discussed, e.g. the issue of relationships between structure of didactic content and structure of teacher activities during the teaching process. With respect to didactics as one of the branches of pedagogy, Karl R. Popper's standpoint is used to discuss the problem of asymmetrical relationships between verification and invalidation of prepositions in the field of didactics.
\end{abstract}

Key words: nationality, didactics, teaching, pedagogy

\section{Kilka wstępnych uwag o racjonalności}

Dydaktyka - zarówno jako działalność praktyczna, jak i dziedzina wiedzy pedagogicznej - podlega różnym ocenom dotyczącym jej racjonalności, opartym na kryteriach, uwzględnianych w związku z różnymi akceptowanymi wartościami, ulokowanymi na jej - nazwijmy to - poziomie praktycznym i poziomie teoretycznym. Niezależnie od poważnych skądinąd implikacji wyłaniających się z wpływów kulturowych i etycznych, codziennie doświadczamy pluralizmu świata wartości, a wśród nich wartości odnoszących się do dydaktyki wraz ze wspomnianymi wyżej poziomami. Zapewne dlatego 
dydaktyka - podobnie jak inne nauki pedagogiczne - nie poddaje się jednoznacznym ocenom wyłaniającym się z wyłącznie jednej racjonalności.

Racjonalność wywołuje w naszym myśleniu liczne skojarzenia. Najczęściej „racjonalny” łączy się z określeniami: rozsądny, wyrozumowany, przemyślany, skuteczny, efektywny. Z racjonalnością mamy jednak poważne kłopoty. Zależna jest ona bowiem od takich bądź innych racji (kryteriów ocen, wartości, strategicznych lub doraźnych celów). Słowem, trudno mówić o jednej racjonalności, zwłaszcza że zawsze pojawia się ona w jakimś określonym kontekście. Opinię taką potwierdzają liczne stanowiska natury filozoficznej czy metodologicznej. Z pewnością zadanie jakiegoś uporządkowania kategorii „racjonalność” jest bardzo trudne, zwłaszcza że niejednokrotnie zderzają się w niej równocześnie wielorakie, uwikłane w nasze myślenie perspektywy i konteksty, ilekroć stajemy wobec pytania, czy coś - na przykład - jakieś działanie jest racjonalne lub nie. Nic zatem dziwnego, że zajmujący się racjonalnością autorzy zmuszeni są do decyzji zawsze w jakimś stopniu arbitralnych, podejmowanych z pełną świadomością, że nie prowadzą one do ujęcia ostatecznie porządkującego i wyczerpującego zagadnienie. Słowem, wobec stopnia skomplikowania materii decyzje w mniejszym lub większym stopniu arbitralne są usprawiedliwione.

Na przykład, Jan Such rozważając racjonalność w kontekście nauki, wyróżnia trzy jej typy: racjonalność pragmatyczną, poznawczą i aksjologiczną ${ }^{1}$. Z kolei Józef Życiński pisze:

W opracowaniach współczesnej filozofii nauki wymienia się co najmniej kilkanaście różnych typów racjonalności: metodologiczną, epistemologiczną, poznawczą, hermeneutyczną, ontyczną, metafizyczną i pragmatyczną ${ }^{2}$.

Należy też zauważyć, że kategoria racjonalności stopniowo mości sobie legowisko na gruncie pedagogiki, a tym samym dydaktyki. Dobrym przykładem jest wydana w 2016 roku monografia autorstwa Bogusława Milerskiego i Macieja Karwowskiego: Racjonalność procesu kształcenia. Teoria i badania ${ }^{3}$. Sięgając do dorobku filozoficznej refleksji nad człowiekiem i edukacją, autorzy porządkują obszar racjonalności w odniesieniu do szkolnej edukacji budując koncepcję tetragonalną, obejmującą racjonalność prakseologiczną, hermeneutyczną, emancypacyjną i negacyjną.

Można zatem twierdzić, że nie ma jednej racjonalności, bo nie ma ujednoliconych jej kryteriów, a w dodatku ujednoliconego kontekstu. Mówimy często, że racjonalny to „oparty na rozumie”, ale przecież trzeba wówczas

${ }^{1}$ J. Such, Nauka i racjonalność, [w:] Nauka. Tożsamość i tradycja, red. J. Goćkowski, S. Marmuszewski, Kraków 1995.

2 J. Życiński, Granice racjonalności. Eseje z filozofii nauki, Warszawa 1993, s. 14.

${ }^{3}$ B. Milerski, M. Karwowski, Racjonalność procesu ksztatcenia. Teoria i badanie, Kraków 2016. 
zapytać, czym w danym momencie kieruje się rozum? Dla przejrzystości wywodu możemy rozróżnić $\mathrm{w}$ tym swoistym chaosie dwa poziomy: poziom racjonalności jednostkowej i poziom - ugruntowanej na przykład kulturowo - racjonalności ponadjednostkowej. I w jednym, i w drugim przypadku racjonalność może oznaczać spójność przekonań, wartości, celów, warunków i działań. Poprzez uwypuklenie kategorii spójności określenie to staje się aksjologicznie neutralne.

Jeśli wkroczymy na grunt edukacji i gdy mówimy o poziomie ponadjednostkowym, to możemy przyjąć, że w myśleniu potocznym zauważamy powszechne wyobrażenie, że „istnieje” tylko jedna racjonalność edukacyjna - ta najważniejsza, bo bezpośrednio "dotykalna”, weryfikowalna za pomocą mierzalnych efektów, wyników testów, administracyjnych decyzji o promocjach, o przyjęciach do określonych szkół, o przyjęciach na studia itp. Taką racjonalność traktuje się najczęściej jako zespół przesłanek, czynników oraz rozwiązań tworzących niezależną od jednostki i dominującą nad nią strukturę. Siłą rzeczy nie można wykluczyć, że nie wpływa ona na osobiste decyzje jednostek. Innymi słowy, myśląc o swojej edukacji i planując ją, w jakiś sposób racjonalizując, jednostka uwzględnia taką - narzuconą, obcą dla niej dość często racjonalność, traktując ją jako zobiektywizowany wyznacznik osobistej wartości, mierzonej zewnętrznymi, a więc "słusznymi, prawdziwymi", bo "obiektywnymi” wyrozumowanymi kryteriami.

\section{Racjonalność dydaktyki jako akademickiego przedmiotu nauczania}

Nawiązując do wcześniejszych ustaleń przyjmujemy, że racjonalność dydaktyki jako akademickiego przedmiotu nauczania może być rozważana w kontekście arbitralnie dobranych kryteriów. Rozważmy więc ją w kontekście pytania o relacje między strukturą dydaktyki jako przedmiotu nauczania a strukturą czynności nauczycielskich. Jest to dość istotna kwestia rozstrzygająca między innymi o przydatności wiedzy dydaktycznej do potrzeb praktyki. Zakładamy, że w czynnościach nauczyciela istnieje pewien określony porządek, podyktowany jego planami. Można więc mówić o jakiejś strukturze jego czynności, na którą składają się określone ich sekwencje, wyodrębnione na podstawie ich właściwości związanych najczęściej ze specyficznymi, niekiedy cząstkowymi celami. $Z$ tych założeń wyłania się zagadnienie relacji pomiędzy tym, co składa się na treść dydaktyki jako przedmiotu nauczania a działaniami nauczyciela.

Łatwo zauważyć, że działania nauczyciela tworzą realnie realizowany proces nauczania. Zagadnieniu temu w tradycyjnej strukturze treści dydak- 
tycznych poświęcono stosunkowo mało miejsca. Dydaktyka w starszej wersji tradycyjnej czyni niekiedy wrażenie wiedzy opisującej zmumifikowany, pozbawiony dynamiki, zastygły świat. To jakby ktoś zrobił pojedyncze zdjęcie, z którego niewiele wynika, co mogło zdarzyć się wcześniej i co może zdarzyć się później. Trzeba dodać, że pod tym względem w polskiej dydaktyce po latach zastoju dokonał sie pewien postęp. Nowsze opracowania podręcznikowe obejmują opisy niektórych procesów nauczania, które jako propozycje wzorcowe mogą z korzyścią służyć nauczycielom.

Współcześnie w polskiej dydaktyce mamy do czynienia z tradycyjnym, historycznie ukształtowanym modelem struktury nauczanych w uczelniach treści dydaktycznych. To swoisty szkielet, na który składają się: cele, treści, metody, zasady, przebieg procesu dydaktycznego, formy organizacji kształcenia, środki dydaktyczne - dodawane ostatnimi czasy systemy dydaktyczne. Model ten był w swoim czasie potrzebny, bo opisywał nauczycielskie instrumentarium, pozwalał nauczycielom z grubsza przyjrzeć się temu, co w swej praktyce mają do dyspozycji i wreszcie kształtował ujednolicony język opisu ich pracy - głównie zaś jej planowania. Jednakże, w fazie realizacji przydatność tego modelu z biegiem czasu okazywała się coraz bardziej ograniczona z kilku co najmniej powodów.

Po pierwsze, w treściach dydaktycznych dominowało podejście, które miało sporo znamion idealizacji rzeczywistości. Innymi słowy, dydaktycy koncentrowali się raczej na idealnym "powinno być" przy marginalizacji realnego ,jest” lub „może być”. To tak, jakby plastyczna rzeczywistość dydaktyczna miała łatwo ulegać wyobrażeniom o pożądanym, optymalnym stanie rzeczy. Mieliśmy więc do czynienia ze schematyzowaniem planowania według z góry przyjętych elementów i w konsekwencji idealizowaniem rzeczywistości przy marginalizacji analitycznego opisu możliwych zdarzeń w fazie realizacji. W tym ujęciu planowanie podporządkowano ujętym w schemacie elementom przy cichym założeniu, że elementy te rzeczywiście pojawią się, czy też dadzą się zauważyć $\mathrm{w}$ realnym procesie dydaktycznym. Tymczasem, podporządkowana myśleniu nauczycieli struktura ich działań mogła znacznie odbiegać od struktury obejmującej sugerowane elementy planowania. Można powiedzieć, że w fazie realizacji nauczyciele byli pozostawiani sami sobie i w swej praktyce gubili znaczną część opisywanego przez tradycyjną dydaktykę instrumentarium, siłą rzeczy kierując się intuicją lub ugruntowanymi nawykami.

Po wtóre, dla części tworzących szkielet struktury dydaktyki elementów z trudem można było wskazać ich odpowiedniki w rzeczywistych działaniach nauczycieli. Klarownym przykładem jest tu obszar metod dydaktycznych - dość wyraźnie eksponowany w programach kształcenia dydaktycznego w szkołach wyższych. Nie dość, że współcześnie jest on wyjątkowo 
zagmatwany i nieuporządkowany, to część metod opisywanych przez dydaktykę jest przez nauczycieli w praktyce na dobrą sprawę nierozpoznawalna, choć być może przez nich znana. Można odnieść wrażenie, że metoda dydaktyczna $\mathrm{w}$ obecnej postaci jest $\mathrm{w}$ stosunku do realnej praktyki kształcenia kategorią zbyt ogólną, zbyt pojemną, a w dodatku kategorią o niejasnych konturach i przez to rozmywa się ona w morzu różnorodnych, drobniejszych rozwiązań dydaktycznych i sekwencji działań nauczyciela. Działania te mogą rozlewać się w poprzek granic dzielących poszczególne metody. Innymi słowy, nauczyciele w praktyce wybierają (często nieświadomie) jakieś elementy jednej i drugiej metody mieszając je, co w sumie może nawet doprowadzać do korzystnych efektów. Pozostaje jednak pytanie o sens wyodrębniania metod nauczania w obecnej postaci, choć zapewne część $\mathrm{z}$ nich ze względu na specyficzne cechy może być w całości stosowalna w praktyce. Jako przykłady można podać gry dydaktyczne lub nauczanie programowane.

Po trzecie, penetrowany przez polską dydaktykę, uporządkowaną na tradycyjną modłę, obszar szybko okazał się zbyt wąski względem całości zdarzeń składających się na to, czego w codziennej praktyce doświadcza nauczyciel. Doświadczana przez nauczycieli szkolna rzeczywistość nie mieściła się już w pojemniku zawierającym tradycyjne elementy dydaktyki ogólnej. Ta dysproporcja zwiększyła się wraz z pojawieniem się nowych definiowanych obszarów, jak program ukryty, style nauczania, myślenie i decyzje nauczycieli wraz z ich refleksyjnością, zdarzenia krytyczne, kierowanie klasą, zarządzanie czasem lekcji, czy cała grupa zagadnień zgrupowanych wokół idei konstruktywizmu dydaktycznego, motywowania uczniów, ich współpracy itd. By przekonać się o tym, wystarczy przejrzeć układy treści tłumaczonych na język polski lub niektórych rodzimych monografii i opracowań podręcznikowych.

Zwykle jest tak, że jeśli do całości dołącza się nowe elementy, to całość tę trzeba na nowo uporządkować. Z jednej więc strony należy pozytywnie ocenić rozszerzenie obszaru analizowanego i badanego przez dydaktykę. Dzięki temu lepiej wpisuje się ona $\mathrm{w}$ potrzeby nauczycieli. $\mathrm{Z}$ drugiej jednak strony wskutek poszerzenia badanego obszaru dydaktyka jako nauczany w szkołach wyższych przedmiot utraciła uprzednie, klarowne, choć upraszczające rzeczywistość uporządkowanie. Pojawiły się nowe obszary słabo jednak powiązane $\mathrm{z}$ obszarami historycznie ugruntowanymi. Można wskazać tu jako przykłady prace Doroty Klus-Stańskiej, Krzysztofa Kruszewskiego, Krzysztofa Konarzewskiego, Stanisława Dylaka, a także autora niniejszego tekstu, czy wreszcie nowsze opracowania podręcznikowe. Można więc mówić o potrzebie ponownej syntezy całości treści dydaktycznych i nadania im w miarę uporządkowanej struktury. 
Trudno obecnie przewidywać, do czego synteza taka może doprowadzić, zwłaszcza że jest to zadanie dość trudne. Swoją rolę odgrywa w tym kontekście korzystny skądinąd proces nawiązywania przez dydaktykę szerszej korespondencji z innymi dziedzinami wiedzy. Wszystko to podpowiada nam potrzebę gruntownego zastanowienia się nad tożsamością dydaktyki jako dziedziny wiedzy adresowanej do nauczycieli.

Oprócz tego istnieje potrzeba redefinicji niektórych zadomowionych od dawna w dydaktyce pojęć. Choć część z nich odegrała wcześniej jakąś pozytywną rolę, to obecnie wobec postępu w licznych dziedzinach może prowadzić do banalizacji i problemowego wyjałowienia treści dydaktycznych. Jako przykład można wskazać pojęcie kształcenia, powszechnie traktowane jako rozwiązanie tradycyjnego sporu o to, co ma nad czym dominować: nauczanie nad uczeniem się czy odwrotnie - uczenie się nad nauczaniem? Kwestia ta stawiana jest najczęściej w kontekście opozycji dwóch dydaktyk: Herbartowskiej i Deweyowskiej. Otóż, przyjęcie tezy, że kształcenie to proces obejmujący nauczanie i uczenie się, a zarazem równoważący je na zasadzie wzajemnego warunkowania i integracji usuwa problem poza debatę, co prowadzi do wniosku, że jest on jedynie pozorny i nieistotny. Tymczasem, w rzeczywistości problem pozostaje i - co więcej - jest istotny tak z teoretycznego, jak i praktycznego punktu widzenia. Trzeba bowiem zadać pytanie o charakter owego zakładanego związku nauczania i uczenia się. Z zaprezentowanego tu rozumienia terminu „kształcenie” wynika, że związek ten ma naturalny charakter - jest po prostu dany. Tymczasem, każdy nauczyciel doświadcza wielokrotnie tego, że ten związek nie jest dany, lecz zadany, że trzeba o niego z wysiłkiem się starać i to $\mathrm{w}$ dodatku w autentycznej współpracy z uczniami. Przy takim podejściu docieramy do bardzo ważnego pola problemowego, które dopiero teraz zaczynamy rozpoznawać.

W treściach współczesnej polskiej dydaktyki można doszukać się wielu innych przykładów usuwania problemów zamiast ich rozwiązywania. Tymczasem, postęp $\mathrm{w}$ nauce polega na odważnym docieraniu do problemów, ujawnianiu ich czy to poprzez dociekania natury czysto teoretycznej, czy to poprzez obserwacje, a następnie podejmowaniu prób ich rozwiązania. Dodajmy, że nowe rozwiązania mogą ujawniać kolejne problemy, które trzeba będzie rozwiązywać - i tak bez końca. Dydaktyka - podobnie jak każda inna nauka - musi żyć, czyli ciągle się zmieniać i ciągle przybliżać do prawdy, bowiem ta zawsze jest bardziej skomplikowana niż to sobie wyobrażamy.

Jeśli przyjmiemy, że racjonalność dydaktyki jako przedmiotu nauczanego w szkołach wyższych oznacza wyrozumowaną spójność przekonań, wartości, celów, warunków i działań, to wniosek nasuwa się sam - stoimy przed długą drogą wymagającą współpracy i integracji wysiłków. 


\section{Racjonalność dydaktyki jako subdyscypliny pedagogicznej}

Jesteśmy nieodrodnymi, ale na swój sposób krnąbrnymi dziećmi Wielkiej Rewolucji Naukowej, która stworzyła naukę w nowożytnej postaci. To ona ukształtowała specyficzny sens słowa "nauka”, przydając mu zarazem konotacji wartościujących. W powszechnym odczuciu nauka ma przynosić nam wiedzę pewną, udokumentowaną, wiarygodną, godną zaufania - właśnie „naukową". Nic zatem dziwnego, że nauka kojarzy się z prestiżem i dlatego sprzyja specyficznej identyfikacji środowiskowej, a także emocjonalnemu przywiązaniu do nobilitującej naukowości oznaczającej poznawczą rzetelność i uczciwość.

Pod względem poznawczym naukowa profesja szczyci się we współczesnych społeczeństwach znaczącym autorytetem i rzeczywiście - gdziekolwiek nauka jako taka jest rozpoznana i wyeksponowana, tam pojawia się oczekiwanie, że zostanie zakomunikowane coś szczególnie wiarygodnego lub rzetelnego. Taki autorytet jest oczywiście dla każdego naukowca wartością nie do przecenienia i dlatego jego utrzymaniem każdy z nich jest osobiście zainteresowany. Można więc oczekiwać, że wszyscy ludzie nauki będą troszczyć się utrzymanie jej granic, by nie dopuścić do wszelkich zewnętrznych ingerencji, które mogłyby narazić ich reputację na szwank, a także dążyć do wykluczenia wszystkiego, co wewnątrz nauki może jej autorytetowi zaszkodzić ${ }^{4}$.

Wielka Rewolucja Naukowa dokonała się poprzez odrzucenie scholastycznego wizerunku świata, a zarazem dzięki sukcesom nauk przyrodniczych. Swój ostateczny triumf odniosła w XVII wieku, wraz z ukazaniem się w 1687 roku Newtonowskich Philosophiale naturalis principia mathematica. Ale przecież na triumf ten złożył się wcześniejszy wysiłek całej plejady wybitnych umysłów. Za początek okresu fundamentalnych dla ówczesnej nauki odkryć można by umownie przyjąć ukazanie się w Norymberdze w 1543 roku De revolutionibus orbium coelestium Mikołaja Kopernika. Do wydania Principiów upłyną więc 144 lata. W tym właśnie okresie dokonają się przełomowe, fundamentalne dla naszego oglądu świata obserwacje - na przykład Tychona Brahe - oraz odkrycia Kopernika, Galileusza, Keplera i wreszcie Newtona. Trzeba też wspomnieć o Novum Organum Francisa Bacona (1620) i Rozprawie o metodzie Kartezjusza (1637). W pracach tych podjęto trud kodyfikacji rozwoju nauki i identyfikacji reguł dochodzenia do rzetelnej wiedzy naukowej.

Pojawienie się nowożytnej nauki dzięki sukcesom nauk przyrodniczych usytuowało kształtujące się nauki społeczne i humanistyczne w kłopotliwej

${ }^{4}$ B. Barnes, D. Bloor, J. Henry, Scientific Knowledge. A Sociological Analysis, Chicago 1996, s. 140 . 
sytuacji. Okazało się, iż jeśli próbują one podążać drogą wytyczoną przez przyrodoznawstwo, czynią to z wielkimi kłopotami, z przygnębiającą świadomością, że przyrodoznawczy ideał naukowości jest dla nich w pełni niemożliwy do osiągnięcia. Szeroko pojmowana rzeczywistość społeczna znacznie trudniej poddaje się promowanemu przez przyrodoznawstwo poznaniu naukowemu niż bezduszna przyroda z jej regularnością, powtarzalnością i dość dobrze dziś rozpoznaną strukturą. Szczególnego znaczenia nabiera właśnie przystosowane środowiskowo rozpoznanie struktury. Mamy poważne trudności z uzgodnieniem tego, co wiemy o strukturze rzeczywistości społecznej. Szczególnie ważną rolę odgrywa w tym kontekście liczba zmiennych uwikłanych w badane zjawiska i zmienność tychże zjawisk wraz z ich licznymi, możliwymi kontekstami.

Różnicę między rzeczywistością społeczną a przyrodą celnie opisał T. Sozański. Z opisu tego można wydobyć dwa ważne twierdzenia, choć oczywiście jest w nim ich znacznie więcej. Po pierwsze, w naukach empirycznych

(...) nie ma zasadniczych kłopotów ze wskazaniem zakresu faktów, które ma wyjaśniać teoria ${ }^{5}$.

Łatwo precyzyjnie określić granice uogólnień, ponieważ klarownie wyłaniają się one z samej struktury badanej rzeczywistości. Tymczasem, granice wyjaśnianego przez teorię społeczną obszaru pozostają do pewnego stopnia rozmyte. Po wtóre,

Szanse budowania w pełni naukowych teorii zjawisk społecznych byłyby realne, gdyby udało się wykryć zbiór zmiennych charakteryzujących jednostkę (grupę, działanie społeczne i inne obiekty społeczne) we wszystkich możliwych kontekstach, z dopuszczeniem alternatywnych sposobów identyfikowania wartości tych zmiennych za pomocą zależnych od kontekstu wskaźników (w różny sposób wyrażających to samo $)^{6}$.

W tej sytuacji w naukach społecznych ukształtowały się dwa nurty, z których jeden podejmuje próby budowania teorii świadomie godząc się na to, że nie spełni ona wszystkich standardów, jakie swym teoriom narzuciło przyrodoznawstwo. Drugi nurt natomiast przyjął wykładnię o całkowitej nieprzystawalności przyrodoznawczego modelu badań do rzeczywistości społecznej i w konsekwencji podjął zadanie budowy osobnego modelu, z którym dziś powszechnie kojarzymy jakościową strategię badawczą. Siłą rzeczy naraziło to zwolenników drugiego rozwiązania na zarzut o nienaukowym charakterze

${ }^{5}$ T. Sozański, Co to jest nauka? [w:] Nauka. Tożsamość i tradycja, red. J. Goćkowski, S. Marmuszewski, Kraków 1995, s. 41.

${ }_{6}$ Tamże, s. 41-42. 
poznawania, a także doprowadziło do pojawienia się w filozofii nauki kwestii linii demarkacyjnej, oddzielającej to, co zgodnie ze standardami przyrodoznawstwa nauką jest, od tego, co nią nie jest.

Bez wątpienia, dydaktyka dzieli los nauk społecznych. Niezależnie jednak od tego spróbujmy pokrótce przyjrzeć się jej - może przekornie - poprzez pryzmat niektórych kanonicznych zasad naukowości obowiązujących w przyrodoznawstwie. W ten bowiem sposób możemy dotrzeć do niektórych osobliwości racjonalności naukowej dydaktyki jako subdyscypliny pedagogicznej. Jako jedna z nauk społecznych siłą rzeczy uwikłana jest we wszelkie dylematy związane z naukową racjonalnością.

Bardzo istotny wpływ na filozofię nauki wywarł Karl R. Popper. Wprowadził on zasadę falsyfikacji. Popper pisze:

Naturalnie tylko wówczas traktuję pewien system jako empiryczny lub naukowy, gdy poddaje się on sprawdzeniu w doświadczeniu. Z rozważań tych wynika, że za kryterium demarkacji należy przyjąć nie weryfikowalność, lecz falsyfikowalność systemu. Innymi słowy, nie wymagam, by jakiś system naukowy można było wybrać raz na zawsze w sensie pozytywnym, wymagam natomiast, by miał on taką formę logiczną, aby testy empiryczne pozwalały na decyzję w sensie negatywnym: musi być możliwe obalenie empirycznego systemu naukowego przez doświadczenie ${ }^{7}$.

Stąd, w myśleniu Poppera falsyfikacja ma dominować nad pozytywną weryfikacją. Innymi słowy, naukę tworzą zdania, które można sfalsyfikować. Jeżeli jakiegoś zdania nie można obalić, to nie może ono zostać włączone do systemu naukowego.

Popperowska zasada falsyfikacji nie może znaleźć w dydaktyce, podobnie jak w całej pedagogice, zastosowania, zwłaszcza że obserwujemy w niej przeciwstawną do propozycji Poppera relację między weryfikowalnością a falsyfikowalnością na korzyść tej pierwszej. Niezależnie od przyjętej perspektywy epistemologicznej, dość często chodzi w pedagogice o potwierdzenie twierdzeń, a niezmiernie rzadko o ich falsyfikację. Nie jest to - nota bene - wyłączną cechą pedagogiki. W jednym ze swych wystąpień Popper obnaża wysiłki na rzecz potwierdzenia trzech szeroko admirowanych w swoim czasie stanowisk: Marksa, Freuda i Adlera.

Najbardziej charakterystycznym elementem w tej sytuacji był dla mnie ów nieprzerwany strumień konfirmacji, obserwacji, które „weryfikowały” powyższe teorie. Właśnie ten punkt był ciągle podkreślany przez ich zwolenników. Marksista nie mógł otworzyć gazety, by nie znaleźć tam na każdej stronie faktów potwierdzających jego interpretacje historii; i to nie tylko w sferze informacji, lecz także w sferze ich przedstawiania, który odsłaniał klasowe nastawienie gazety, a w szczególności w tym, czego

\footnotetext{
${ }^{7}$ K.R. Popper, Logika odkrycia naukowego, Warszawa 1977, s. 39-40.
} 
gazeta nie mówiła. Psychoanalitycy Freuda podkreślali, że ich teorie były ciągle weryfikowane przez „obserwacje kliniczne" ${ }^{\prime}$.

Orientacja na potwierdzenie twierdzeń stawia dydaktyków w obliczu niebezpieczeństwa naiwnej, upraszczającej ich afirmacji przy marginalizowaniu mogących nasunąć się niekiedy wątpliwości. W skrajnych przypadkach może to grozić zbliżeniem pedagogiki do scholastyki, zwłaszcza że mnogość i różnorodność stanowisk pedagogicznych jest czynnikiem ułatwiającym ich podporządkowaną własnym, partykularnym celom eksploatację. Niekiedy ma się wrażenie, że przy odpowiednim doborze wybranych z literatury stanowisk można wykazać słuszność każdego twierdzenia. W tej sytuacji znaczenia nabierają postulaty sformułowane nawet już dawno temu przez Kartezjusza. Niełatwo jednak doszukać się w pedagogice stanowiska, które zostałoby przez ogół dydaktyków w całości odrzucone, co nie oznacza, że wokół niektórych z nich nie są prowadzone spory. Orientacja na poparcie twierdzeń oznacza też swoisty model rozwoju pedagogiki, oparty na procesie kumulacji stanowisk, a nie - jak to ma miejsce w przyrodoznawstwie - na ich selekcji.

Mamy więc w dydaktyce taką sytuację, że tworzymy ugruntowane w systemach jakichś przesłanek twierdzenia, a następnie emocjonalnie do nich przywiązani wyszukujemy wspierających je argumentów. Dość często nie jest to zbyt trudne, zważywszy na bardzo rozległą ich bazę. Można więc swobodnie poruszać się w obszarach dydaktyki, pedagogiki oraz nauk ją wspierających i czerpać z nich twierdzenia, które akurat zbliżają nas do naszych celów. Pedagodzy - a wśród nich dydaktycy - stawiają siebie często w kłopotliwej sytuacji w świetle kryteriów rzetelności naukowej. Będąc autorami twierdzeń, dążą do ich potwierdzenia. Stają się tym samym sędziami we własnych sprawach. Skoro dotychczas osiągnęliśmy jakąś wiedzę o świecie dzięki władzy rozumu i poddającą się jej, to znaczy, że badany świat jest racjonalny. Ale $\mathrm{w}$ dydaktyce to my w istotnej mierze kształtujemy racjonalność świata edukacji - gdzie są więc kryteria jego racjonalności? Gdzie jest instancja osądzająca, co jest racjonalne? Znów widzimy, że jesteśmy sędziami we własnej sprawie - i ta świadomość $\mathrm{w}$ istotnej mierze warunkuje rzetelność naszych badań.

Wydaje się, że wbrew pozorom sytuacja ta wcale nie ułatwia dydaktykom docierania do rzetelnie ugruntowanych naukowo twierdzeń. Wobec wspomnianej łatwości $\mathrm{w}$ wyszukiwaniu argumentów wspierających głoszone poglądy nakłada ona bowiem obowiązek szczególnej ostrożności i - znów warto to powtórzyć - kierowania się zasadami postulowanymi przez Kartezjusza, a także dążenia (choć nie zawsze jest to możliwe) do potwierdzeń natury empirycznej. Nie należy też odrzucać Popperowskiej zasady falsyfikacji. To

\footnotetext{
${ }^{8}$ K.R. Popper, Problem demarkacji, Zagadnienia Filozoficzne w Nauce, 1995, XVII, s. 3.
} 
właśnie w niej odzwierciedlają się najistotniejsze cechy, które komentując poglądy Poppera Michał Heller określił jako „intelektualna moralność” i „krytyczny racjonalizm"

Dodajmy, że kierując się takimi wartościami Popper zauważa, że w pierwszej fazie dochodzenia do odkrycia pojawia się "gorąca" emocjonalnie faza jego afirmacji, po której powinna pojawić się „chłodna” faza krytycznej analizy logicznej.

Osobnym, choć równie ważnym zagadnieniem jest kwestia koordynacji programów badawczych. Koordynację osiąga się najczęściej poprzez uzgodnienie tego, co wiemy i tego, czego nie wiemy. Jeśli pominąć ważną skądinąd kwestię udokumentowanej odpowiednimi analizami pewności, to orientacja na potwierdzenie twierdzeń pozwala najczęściej osiągnąć świadomość tego, co wiemy. Równocześnie orientacja ta utrudnia uzgodnienie tego, czego nie wiemy i powoduje, że docieranie do niewiadomego staje się indywidualną sprawą dydaktyka. Skoro bowiem nie odrzucono żadnego stanowiska, to nie pojawia się nurtujące pytanie, czym je zastąpić. W dydaktyce innowacyjność badawcza polega najczęściej na indywidualnej pomysłowości w formułowaniu pytań. Nie oznacza to, oczywiście, że nie obserwujemy zespołowych wysiłków badawczych zogniskowanych na uzgodnionych obszarach problemowych. Tak czy inaczej dostrzegamy znaczną autonomię programów badawczych.

M. Heller twierdzi, że nauka (w tym ujęciu przyrodoznawstwo) charakteryzuje się swoistą agresywnością, skierowaną na problemy pojawiające się na jej granicach. To właśnie tu, w strefie styku tego, co wiadome z tym, co niewiadome, wytwarzane jest wewnątrz nauki ciśnienie poszerzające jej obszar.

Teren pogranicza jest zawsze niespokojny. Tu metoda funkcjonuje na granicy swoich możliwości. Zagadnienia, jakie się tu porusza, są największym wyzwaniem i zwykle one niosą najbardziej prowokujący "ładunek filozoficzny”. Nic zresztą dziwnego - linia graniczna między tym, co już wiemy, a Wielkim Nieznanym zawsze była i będzie wezwaniem do głębszej refleksji ${ }^{10}$.

Łatwo zauważyć, że ta metaforycznie nakreślona refleksja słabo pasuje do pedagogiki. Trudno doszukać się w niej stwierdzeń, że czegoś jeszcze nie wiemy. Najczęściej w dydaktyce dążymy do cząstkowych konkluzji, mniej uwagi poświęcając pytaniu, z jakimi konkluzjami pozostają one w sprzeczności. Sytuacja ta odzwierciedla wspomnianą tu niską koordynację programów badawczych i brak środowiskowych uzgodnień dotyczących niewiadomego. Wyłania się stąd potrzeba teoretycznie zaawansowanego dyskursu problematyzującego przedmiot (przedmioty) poznania. Wydaje się, że jakąś

\footnotetext{
${ }^{9}$ M. Heller, Filozofia przyrody. Zarys historyczny, Kraków 2005, s. 169 i n.

${ }^{10}$ M. Heller, Kosmologia kwantowa, Warszawa 2001, s. 11-12.
} 
perspektywę $\mathrm{w}$ tej dziedzinie otwierają naturalne dla rzeczywistości dydaktycznej sprzeczności i związana z nimi dylematyczność.

Prawdopodobnie mamy też do czynienia z nieuprawnionym i nie zawsze uświadamianym utożsamianiem samego odkrycia z drogą prowadzącą do pytania badawczego. Samo odkrycie może wymykać się z kanonów obowiązującej racjonalności, co zresztą zostało zauważone przez K.R. Poppera. Czy jednak to samo można powiedzieć o drodze do pytania leżącego u podłoża odkrycia? O ile odkryciem mogą rządzić różne, pozostające poza świadomą kontrolą intuicje, a wraz z nimi „intelektualne współodczuwanie z przedmiotami doświadczenia"11, o tyle droga do pytania oznaczającego identyfikację obszaru niewiedzy powinna być racjonalna - to znaczy mieć swój początek w tym, co wiadome, a koniec w tym, co niewiadome. Otwiera się wówczas perspektywa wpisania dorobku badań w istniejącą już mapę twierdzeń. Taka droga oznacza też krytyczną analizę tego, co wiadome. Natomiast, intuicyjne docieranie do pytań badawczych może spowodować, że dorobek badania (najczęściej w pedagogice badania przyczynkarskiego) pozostanie w izolacji. Naukowe znaczenie dorobku badań często zależy od tego, czy uda się go wpisać w istniejącą mapę istotnych w danej dziedzinie twierdzeń.

Ze względu na rozmiar niniejszego opracowania, podjęte tu zagadnienia są z pewnością zbyt rozległe, by dokonać ich gruntowniejszej analizy. Chodziło tu raczej o zasygnalizowanie wybranych kwestii. Stawianie pytan o racjonalność dydaktyki jako przedmiotu nauczanego w szkołach wyższych i jako subdyscypliny pedagogicznej budzi z pewnością zawsze potrzebne w nauce myślenie krytyczne, które leży u podłoża społecznego procesu kontroli wprowadzanych do systemu nauki twierdzeń.

\section{BIBLIOGRAFIA}

Barnes B., Bloor D., Henry J., Scientific Knowledge. A Sociological Analysis, The University of Chicago Press, Chicago 1996.

Brockman J. (red.), Trzecia kultura, Wydawnictwo CIS, Warszawa 1996.

Coveney P., Highefield R., Granice ztożoności. Poszukiwania porzadku w chaotycznym świecie, Prószyński i S-ka, Warszawa 1997.

Grobler A., Metodologia nauk, Wydawnictwo Aureus, Wydawnictwo Znak, Kraków 2006.

Heller M., Kosmologia kwantowa, Prószyński i S-ka, Warszawa 2001.

Heller M., Filozofia przyrody. Zarys historyczny, Wydawnictwo Znak, Kraków 2005.

Konarzewski K., Jak uprawiać badania oświatowe. Metodologia praktyczna, Wydawnictwa Szkolne i Pedagogiczne, Warszawa 2000.

${ }^{11}$ Określenie Alberta Einsteina. 
Kuhn T., Struktura rewolucji naukowych, Fundacja Aletheia, Warszawa 2001.

Milerski B., Karwowski M., Racjonalność procesu kształcenia. Teoria i badanie, Oficyna Wydawnicza Impuls, Kraków 2016.

Newton R.G., Zrozumieć przyrodę, Prószyński i S-ka, Warszawa 1996.

Popper K.R., Problem demarkacji, Zagadnienia Filozoficzne w Nauce, 1995, XVII.

Popper K.R., Logika odkrycia naukowego, Państwowe Wydawnictwo Naukowe, Warszawa 1997.

Sady W., Spór o racjonalność naukową. Od Poincarégo do Laudana, Wydawnictwo Funna, Wrocław 2000.

Snow C.P., The Two Cultures, Cambridge University Press, London 1996.

Sozański T., Co to jest nauka? [w:] Nauka. Tożsamość i tradycja, red. J. Goćkowski, S. Marmuszewski, Wydawnictwo Universitas, Kraków 1995.

Stróżewski W., Wielość nauki i jedność wiedzy, [w:] Nauka. Tożsamość i tradycja, red. J. Goćkowski, S. Marmuszewski, Wydawnictwo Universitas, Kraków 1995.

Such J., Nauka i racjonalność, [w:] Nauka. Tożsamość i tradycja, red. J. Goćkowski, S. Marmuszewski, Wydawnictwo Universitas, Kraków 1995.

Życiński J., Granice racjonalności. Eseje z filozofii nauki, Państwowe Wydawnictwo Naukowe, Warszawa 1993. 
